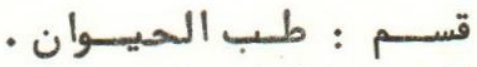

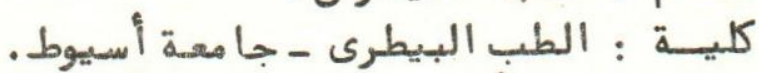

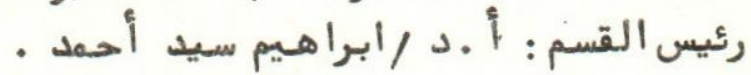

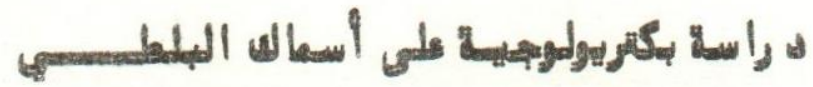 في محافظة أمســـيوط
}

ليلى صلاح الد ين ، ريم د سوقي ، ، يوسف كامل * ابراهيم سـيد ،

$$
\text { عبد المعزز اسماعيل }
$$

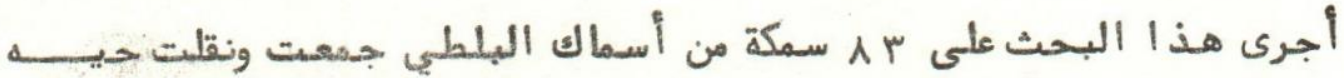

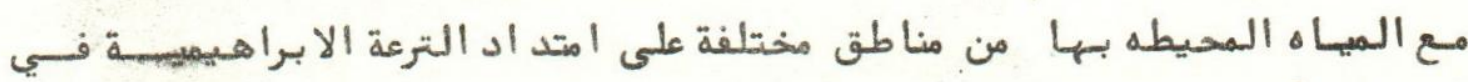

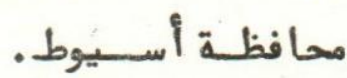

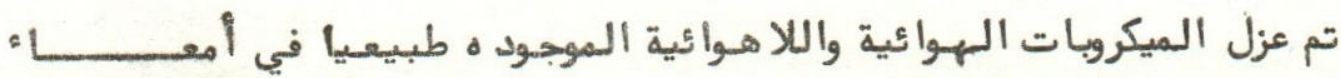

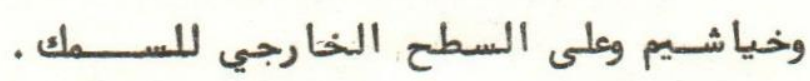

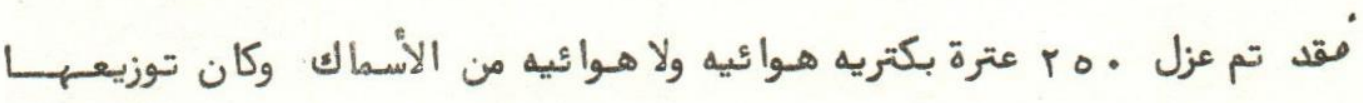

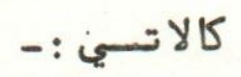

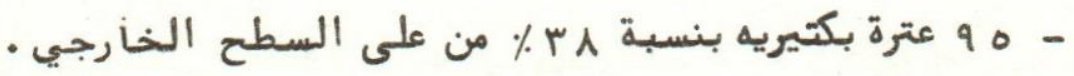

$$
\begin{aligned}
& \text { - } \\
& \text { - }
\end{aligned}
$$

$$
\begin{aligned}
& \text { * قسم صحة الحيوان ـ كلية الطب البيطرى }
\end{aligned}
$$

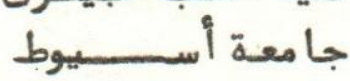



Dept. of Animal Medicine,

Faculty of Vet. Med., Assiut University,

Head of Dept. Prof. Dr. I.S. Abdallah.

\title{
BACTERIOLOGICAL STUDIES ON FRESH WATER FISH (TILIPIA NILOTICA) IN UPPER EGYPT \\ (With 4 Tables)
}

\author{
By \\ LAILA S. AHMED; REEM M. DOSOKY*; Y.Y. KAMEL*; I.S. ABDALLAH \\ and A.A. ISMAIL * \\ (Received at 14/7/1985)
}

\begin{abstract}
SUMMARY
A total of 83 living Tilipia nilotica were bacteriologically examined. The obtained results revealed the detection of 235 bacterial isolates. Of these 91 (38.72\%) were recovered from the surface, 81 (34.46\%) from the gills and 63 (26.80\%) from the intestine. Out of the bacterial isolates, the following species were met with: 2 Haemolytíc strepococci, 42 Enterococci, 66 Coagulase +ve and -ve Staphylococcus aureus, 108 Enterobacteria, 13 Pseudomonas fluoresence, 1 Listeria monocytogenes, 1 Erysipelothrix insidiosa and 2 Clostridium perfringens.

The animal and public heath significance of the recovered strains were discussed.
\end{abstract}

\section{INTRODUCTION}

Man's interest in teleost fish is multificeted. His primary pre-occupation has been the persuit of fish as a source of high biological value protein food: During recent years, the Egyptian Government has embarked on a programme of intenssive fishing of all available water sources. However, fish may become actively infected or subjected to a variety of pathogens resulting in serious pathological affections as well as significant economic hazzards among fish population in both natural and artificial aqua culture resources. In addition, fish may be contaminated from its surroundings with some other microbes of major puplic and animal health significance and certain outbreakes among human beings as well as animals especially dogs and cats are still traced to fish on numerous occasions. (JANSSEN \& MAYER, 1968; BEXTON \& FRAZER, 1977). Moreover Enteric pathogens have been identified in fish from polluted water and under these circumstrances fish act as temporary carrier (LAWSON, 1970 and BROWN \& DOZN, 1977).

It is our intent to isolate, in this work, the bacteria of epidemiological significance from Tilipia nilotica.

\section{MATERIAL and METHODS}

A total of 83 living Tilipia nilotica were cought from different localities of River Nile and El-Ebrahimia Canal at Assiut City. The fish were transferred with the minimum of

* Dept. of Animal Hygiene, Fac. of Vet. Med., Assiut Univ.

Assiut Vet.Med.l. Vol. 15, No. 30, 1986. 
LAlLA S. AHMED, et al.

delay to the laboratory in large sterile jars filled with the river water. The jars containing fish and water were bacteriologically investigated.

Specimens of fish were obtained from the surfaces, gills and intestines. Samples from the surface were collected by the swab method. Eight swabs were used for each fish. Every swab was moistened with sterile saline and rolled 3-4 times over the surface of the fish before being immersed in one of the enrichment media. Specimens from gills were aseptically taken in small pieces and immersed in another tubes containing the proper media. Parts of the intestine were aseptically dissected and transferred to a third tube containing the selective liquid medium.

The sediment obtained from centrifugation of $100 \mathrm{ml}$ of the water of every specimens was also inoculated into the same enrichment media.

Isolation and identification of each microorganism was fullfilled according to MERCHANT \& PAKER, 1967; CRUICKSHANK, et al. 1974; BAILEY \& SCOTT, 1974; BUCHANAN \& GIBBONS, 1974; WILSONS \& MILES, 1975 and JAWETZ, et al. 1976 and entailed the following:

\section{Haemolytic streptococci:}

Nutrient broth was used as enrichment medium-Crystal violet blood agar as well as blood agar were subcultured from the incubated 24 hours broth and incubated at $37^{\circ} \mathrm{C}$ for 24 hours. Identification of the pure cultures was based on growth character and biochemical activities.

Streptococcus faecalis and Streptococcus faecium:

Streptococcus faecalis (SF) broth was inoculated with the different specimens and incubated at $37^{\circ} \mathrm{C}$ for $18-24$ hous. MacConkey's agar plates subcultured from the inoculated broth were similarly incubated for 24 hours. Representive colonies were identified according to thier culture characters and biochemical activities.

\section{Staphylococcus aureus:}

$\mathrm{Nacl}$ broth was used as enrichment medium. Mannitol salt agar and staph 110 were subcultured from the inoculated broth and incubated at $37^{\circ} \mathrm{C}$ for 24 hours. The mannitol fermenting pure cultures were examined for haemolysis on blood agar and for coagulase activity.

\section{Enterobacteria:}

MacConkey's broth as well as Selenite F. broth were inoculated with each specimn and incubated at $37^{\circ} \mathrm{C}$ for 18 hours. Subcultures were carried on MacConkey's and S.S. agar plates and incubated at $37^{\circ} \mathrm{C}$ for 24 hours. Identification of the pure cultures was based ongrowth characteristics and biochemical reactions.

\section{Pseudomonas fluoresence:}

Nutrient broth was used as enrichment medium. Nutrient agar plates were subcultured from the inoculated broth and incubated at $37^{\circ} \mathrm{C}$ for 24 hours. The colonies were identified according to its culture character and biochemical activities.

\section{Listeria monocytogenes:}

Neomycin broth was used as a selective liquid medium. Subcultures were carried on Neomycin blood agar and incubated at $37^{\circ} \mathrm{C}$ for $24-48$ hours. Suspected colonies were identified microscopically, biochemically and by pathogenicity to mice when subcutaneously injected. 


\section{BACTERIOLOGICAL STUDIES ON FRESH WATER FISH}

\section{Erysipelothrix insidiosa:}

Sodium azide crystal violet broth was used as enrichment medium. Subcultures were carried on sodium azide crystal violet blood agar and incubated at $37^{\circ} \mathrm{C}$ for $24-48$ hours. Suspected colonies were identified microscopically and biologically by inoculation of white mice.

\section{Clostridium perfringens:}

Thioglycollate broth was inoculated with the different samples and incubated at $37^{\circ} \mathrm{C}$ for 48 hours. Subcultures were done on neomycin glucose blood agar and incubated anaerobically at $46-47^{\circ} \mathrm{C}$ for 48 hours. Suspected colonies were identified biochemically and biologically by subcutaneous inoculation of white mice.

\section{RESULTS and DISCUSSION}

A total of 235 bacterial isolates were recovered from the 83 examined fish. Of these 91 (38.72\%) were detected from the surface, 81 (34.46\%) from gills and 63 (26.80\%). from the intestine.

Out of the bacterial isolates, the following species were met with: 2 Haemolytic streptococci, 42 Enterococci, 66 Coagulase +ve and -ve Staphylococcus aureus, 108 Enterobacteria, 13 Pseudomonas fluoresence, Listeria monocytogenes, 1 Erysipelothrix insidiosa and 2 Clostridium perfringens.

An outstanding feature in our results is the detection of Listeria monocytogenes in the gut of one fish (Table II). The identification of this strain is based on its cultural character, biochemical behaviour and pathogenicity test. The P.M. examination of the white mice inoculated with suspected growth showed severe hyperaemia of all the parenchymatus organs and adrenal glands and severe congestion of their blood vessels and capillaries. In addition small focal necrotic areas, moderately infiltrated with mononuclear leucocytes and few neutrophilis were observed in the liver and kidney. Myocardial degeneration and necrosis as well as mononuclear cell infiltration were also found.

Erysipelothrix insidiosa was only recovered from the surface of one fish, representing $0.42 \%$ (Table III). It was previously isolated by many workers from fresh water fish as STAURT, 1938; SHEWAN, 1972 and NABILAH MAHMOUD, 1975.

Haemolytic streptococci were only detected from the surface of two fish (0.85\%). Such pathogen was previously isolated by many workers from fresh water fish. It was found to be an etiologically significant agent in some epizootics among Tilipia nilotica and other fresh water fish (KITAO, et al. 1981). The affected fish are characterized by external petechial haemorrhages around the anus and ventral body surface, secrtion of abnormal slime on the gills, excessive redish asciatic fluid accumulation in the body cavity and namerous haemorrhages in the intestine (UGAJIN, 1981).

Enterococci were recovered from the different parts of the examined fish representing 17.87 percent (Table 1). They include Streptococcus faecalis (13.61\%) and Streptococcus faecium $(4.25 \%)$. The pathogenicity of such organisms on fish is not clearly recognizet: However the presence of detectable number of these two strains on or in the fish is an indicativ, of pollution of water with sewage and animal wastes.

Staphylococcus aureus was isolated from the different parts of the examined is: representing 28.08 percent. Of these 7 (2.97\%) were coagulase +ve Staphylococcus aureus and

Assiut Vet.Med.J. Vol. 15, No. 30, 1986. 
LAILA S. AHMED, et al.

$59(25.1 \%)$ were coagulase -ve one. The occurrance of this organism in the different types of fish was previously recorded by many authors as SHEWAN, 1962 and SARKIEWIEZ, et al. 1968.

Enterobacteria were the most common organisms isolated from fish (Table II). They formed 108 (45.95\%) strains. Of these strains $1(0.42 \%)$ was Shigella flexenari, 12 (5.10\%) E. coli 61 (25.95\%) Proteus species, 18 (7.65\%) Klebsiella species, 8 (3.40\%) Arizona species, 5 (2.12\%) Aerobacter and $3(1.27 \%)$ Citrobacter. However the occurrence of these organisms especially on the slime of the fish also serves as an index of faecal pollution of such fish from water supplies. Besides many species of these microorganisms were found to be pathogenic for fresh water fish. It was frequently isolated from cases of spottiness of the skin. The affected fish show "Corroded" spots, ecchymoses and later secondary fungus infection (DUIJN, 1973).

Pseudomonas fluoresence was recovered from 13 specimens of examined fish representing (5.53\%). This organism was encountered in cases of spottiness of the skin (DUIJN, 1973) and haemorrhagic bacterial septicaemia (ROBERTS, 1978) among different species of fish.

Clostridium perfringens was only isolated from the intestine of two fishes (0.85\%). This result was in accordance with the finding of BROWN (1917) who succeeced in isolating such pathogen from stenomus Chrysops. Also SHEWAN, 1962 and BARROW \& MILLER, 1972 could isolate Clostridium perfringens from fishes.

It is clearly evident from Table IV that fish might reflex to a certain extent the bacteriological condition of water and these be a potential indication of pollution with different species of bacteria especially Streptococcus faecalis, haemolytic streptococci, Staphylococcus aureus, E. coli, Proteus morganii, Proteus rettgeri, Proteus vulgaris, Arizona and Pseudomonas fluoresence. On the other hand Streptococcus faecium, Shigella flexenari, proteus mirabilis, klebsiella species, Aerobacter, citrobacter, Listeria monocytogens, Erysipelothrix insidiosa and Clostridium perfringens could be detected only from fish and water become free from such organisms.

Regardless the pathogenic significance of these bacterial isolates on fish which will be experimentally carried out on a second part of this work. It is clearly evident from our results that fish may act as a vector of certain illnesses to human being as well as animals, especially the fish eating ones. The isolation of pathogenic and potentially pathogenic bacteria from fish especially haemolytic streptococci, coagulase +ve Staphylococcus aureus, Shigella flexenari, Listeria monocytogenes, Erysipelothrix insidiosa and Closteridium perferingens proved that these cold-blooded animals share with other reservoir animals the responsibility of transmitting these agents to man and animals.

\section{REFERENCES}

Bailey, W.R. and Scott, E.G. (1974): Diagnostic microbiology. 4th Edition, the C.V. Mosby company, Saint Ic uis.

Barrow, G.I. and Mille, D.C. (1972): Vibrio parahaemolyticus: A potential pathogen from marine sour' $c$ 's in Britain. Lancet, I, 485-486.

Brown. W. (1917\% The presence of E.Coli and B.Welchii groups in the intestinal tract of fish $\therefore$ enomus Chrysops. J. Bact. 2, 417-422.

Brown, L.n and Dozn, C.R. (1977): Fish, Shellfish and Human Health. J. Food production, 40, $712-717$. 


\section{BACTERIOLOGICAL STUDIES ON FRESH WATER FISH}

Buchanan, R.E. and Gibbons, N.E. (1974): Bergeys manual of determinative bacteriology. 8th Ed. The Williams \& Wilkins company, Baltimore.

Buxton, A. and Fraser, G. (1977): Animal Microbiology. Vol. 1st Ed. Blackwell Scientific fubl., Oxford.

Cruickshank, R.; Duguid, J.P. and Swain, R.H.A. (1974): Medical microbiology 11th Ed. E.\&S. Livingstone Led., Dinburgh and London.

Duijn, C. Van (1973): Dieases of Fishes. 3rd Ed. London I liffe Books.

Halstead, W. Bruce (1962): Biotoxications, Allergies and other Disorders in fish as food. Vol. II. p. 521, Edited by G. Borgstrom, Academic press, New York and London.

Horodnieeau, T. and Sasarman, A. (1964): Methods of isolating Cl. perfringens V. comparason of some media. Archsroum. path. Microbiol., 23, 633-640.

Janssen, W.A. and Meyers, D.C. (1968): Fish serological evidance of infection with human pathogens. Science, $159,547$.

Jawetz, E.; Melnick, J.L. and Adelberg, E.A. (1976): Review of Medical Microbiology, 12th Ed. Long medical puplications, Los Altos, California.

Kitao, T.; Aoki, T. and Sokoh, R. (1981): Epizootic caused by B-Haemolytic Streptococcus species in cultured', fresh water fish. Fish pathology 15, (314), 301-307.

Lawson, J.B. (1970): Some aspects of fish inspection and public health. Vet. Rec., 87, 528.

Marchant, I.A. and Packer, R.A. (1967): Veterinary bacteriology and Virology. 7th Ed. The lowa state University press. Amesterdam, Lora, U.S.A.

Maurer, F.D. (1969): Fish health a requisite of fish culture. J. Am. Vet. Med. Ass. 154, 1596-1599.

Mossel, D.A.A.; Brouwers, G. and De. Bruin, A.S. (1959): A simplified method for isolation and study of obligate anaerobes. J. Path. \& Bact., 78, 1, 290-291.

Nabilah, M. Mahmoud (1975): Bacteriological and Serological study onfresh water fish in Upper Egypt. Thesis for M.D. Degree (Bacteriology). Assiut University.

Roberts, J.R. (1978): Fish Pathology. Bailliere Tindall. London.

Sarkiewiez, B.F.; Groomes, R.J. and Shalton, L.R. (1968): Bacteriological survey of the frozen prepared food industry, IV, frozen bread fish. appl. Microbiol. 16, 147-150.

Shewan, J.M. (1962): Food Poisoning caused by fish, fish as food. Vol. II, Edited by G. Borgstrom, Academic press, New York and London p. 443.

Stuart, L.S. (1938): Isolation of halophilic bacteria from Soil water and dung. Food Research, 3, 417-420.

Ugajin, M. (1981): Studies on Streptococcus species as a causative agent of an epizootic among the cultured Ayu (plecoglossus activities) in Tochigi prefecture, Japan Fish pathology 16 (3) 119-127.

Wilson, G.S. and Miles, A. (1975): Topley and Wilsons principales of bacteriology, virology and immunity 6th Ed. Vol. 2. Edward Arnold Ltd., London. 
LAILA S. AHMED, et a․

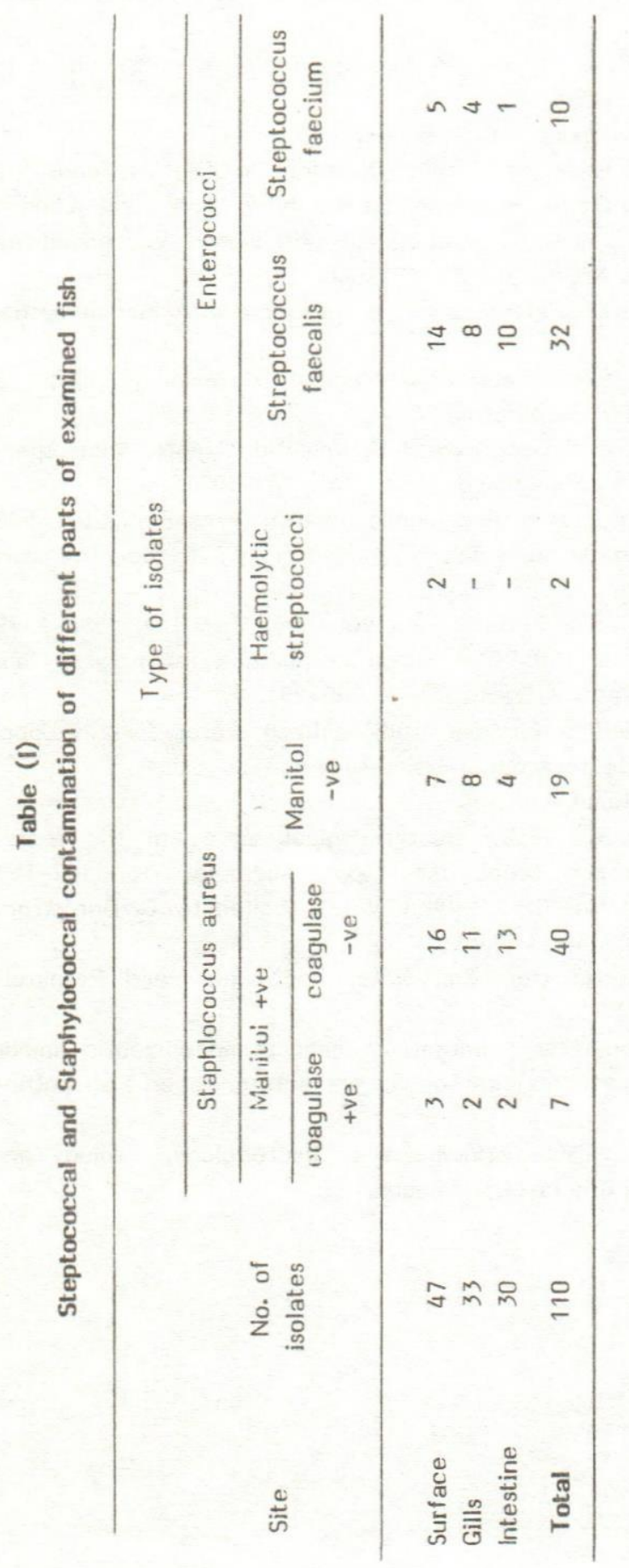

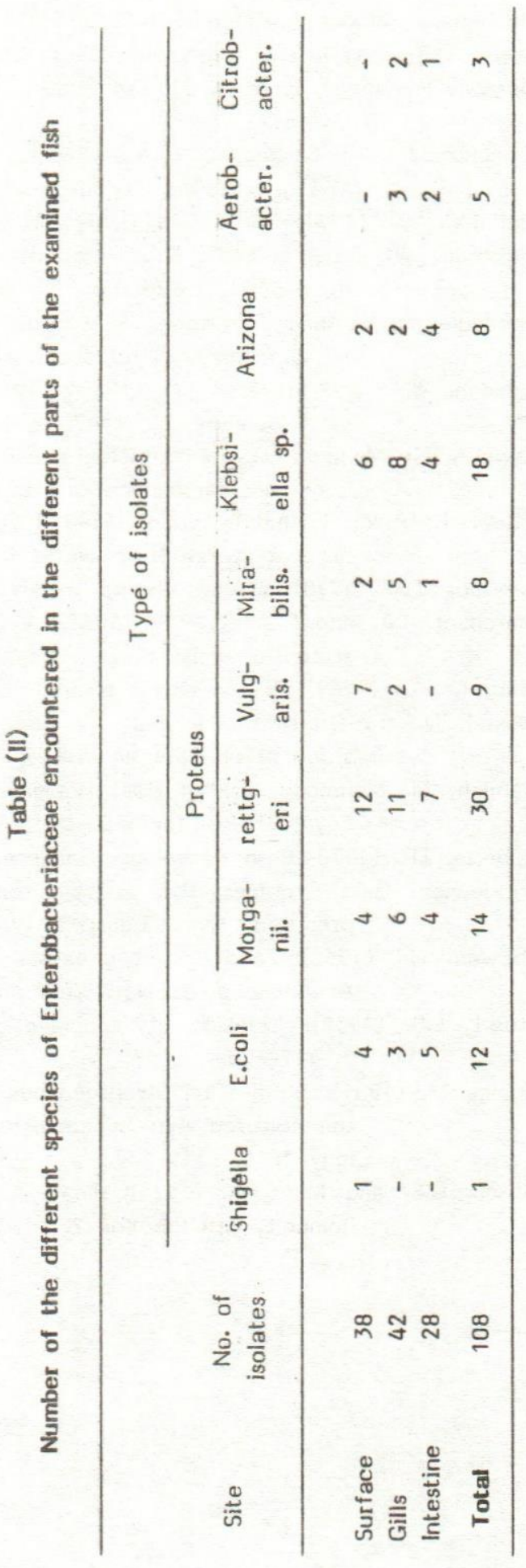




\section{BACTERIOLOGICAL STUDIES ON FRESH WATER FISH}

Table (III)

Other types of bacteria isolated from the different parts of the examined Tilipia nilotica

\begin{tabular}{|c|c|c|c|c|c|}
\hline \multirow[b]{2}{*}{ Site } & \multirow[b]{2}{*}{$\begin{array}{l}\text { No. of } \\
\text { isolates }\end{array}$} & \multicolumn{4}{|c|}{ Type of isolates } \\
\hline & & $\begin{array}{l}\text { Listeria } \\
\text { monocytogenes }\end{array}$ & $\begin{array}{l}\text { Erysipelothrix } \\
\text { insidiosa }\end{array}$ & $\begin{array}{l}\text { Pseudomonas } \\
\text { fluoresence }\end{array}$ & $\begin{array}{l}\text { Clostridium } \\
\text { perfringens }\end{array}$ \\
\hline Surface & 6 & - & 1 & 5 & - \\
\hline Gills & 6 & - & - & 6 & - \\
\hline Intestine & 5 & 1 & - & 2 & 2 \\
\hline Total & 17 & 1 & 1 & 13 & 2 \\
\hline
\end{tabular}

Table (IV)

Frequency percentage of the different species of bacteria isolated from fish and water

\begin{tabular}{|c|c|c|c|c|c|}
\hline \multirow[b]{2}{*}{ Type of isolates } & \multirow{2}{*}{$\begin{array}{l}\text { Total } \\
\text { No. of } \\
\text { isolates }\end{array}$} & \multicolumn{2}{|c|}{ From fish } & \multicolumn{2}{|c|}{ From water } \\
\hline & & No. & $\begin{array}{c}\text { Frequency } \\
\%\end{array}$ & No. & $\begin{array}{c}\text { Frequency } \\
\%\end{array}$ \\
\hline Staphylococcus aureus & 10 & 7 & $70.00 \%$ & 3 & 30.00 \\
\hline Staphylococcua aureus & 47 & 40 & $85.11 \%$ & 7 & 14.89 \\
\hline Streptococcus pyogenes & 3 & 2 & $66.66 \%$ & 1 & 33.44 \\
\hline Streptococcus faecalis & 40 & 32 & $80.00 \%$ & 8 & 20.00 \\
\hline Streptococcus faecium & 10 & 10 & $100 \%$ & - & - \\
\hline Shigella flexeneri & 1 & 1 & $100 \%$ & - & - \\
\hline E. coli & 16 & 12 & $75.00 \%$ & 4 & 25.00 \\
\hline Proteus morganii & 20 & 14 & $70.00 \%$ & 6 & 30.00 \\
\hline Proteus rettgeri & 32 & 30 & $93.75 \%$ & 2 & 06.25 \\
\hline Proteus vulgaris & 15 & 9 & $60.00 \%$ & 6 & 40.00 \\
\hline Proteus mirabilis & 8 & 8 & $100 \%$ & - & - \\
\hline Klebsiella sp. & 18 & 18 & $100 \%$ & - & - \\
\hline Arizona & 9 & 8 & $88.89 \%$ & 1 & 11.11 \\
\hline Aaerobacter & 5 & 5 & $100 \%$ & - & - \\
\hline Citrobacter & 3 & 3 & $100 \%$ & - & - \\
\hline Pseudomonas & 17 & 13 & $76.47 \%$ & 4 & 23.53 \\
\hline Listeria & 1 & 1 & $100 \%$ & - & - \\
\hline Erysipelothrix insidiosa & 1 & 1 & $100 \%$ & - & - \\
\hline Clostridium perfringens & 2 & 2 & $100 \%$ & - & - \\
\hline Total & 258 & 216 & 83.75 & 42 & 16.25 \\
\hline
\end{tabular}

